\title{
Presence of Beania mirabilis Johnston in the Gulf of San Matias (Argentina), with a key to the Argentine species of Beania (Bryozoa, Cheilostomatida)
}

\author{
Juan LÓPEZ GAPPA \\ Museo Argentino de Ciencias Naturales «Bernardino Rivadavia», Av. A. Gallardo 470, C1405DJR Buenos Aires, \\ Argentina. E-mail: Igappa@mail.retina.ar

\begin{abstract}
Beania mirabilis Johnston is recorded for the first time in Argentina. It was found on bivalve shells and polychaete tubes in the intertidal and subtidal zones of the Gulf of San Matias $\left(40^{\circ} 46^{\prime} \mathrm{S}, 64^{\circ} 55^{\prime} \mathrm{W}\right.$, province of Rio Negro, Argentina). This record increases in more than $16^{\circ}$ of latitude its southern distribution limit in the southwest Atlantic Ocean. An illustrated key for the identification of the eight species of Beania known for the Argentine Sea is included.
\end{abstract}

Key words: Bryozoa, Cheilostomatida, Beania, key to species, Argentina

The genus Beania Johnston, 1840 , comprises more than 50 species distributed throughout the world's oceans, including Antarctica. Beania is characterized by its reticulate or ramifying colonies, with zooids loosely attached to the substratum by rhizoids issuing from their basal surfaces, and connected by tubular extensions.

Several species of Beania have been already recorded for the coast and the continental shelf of Argentina (see Hastings, 1943; Amor \& Pallares, 1965; López Gappa \& Lichtschein, 1990). The geographic distribution of B. costata (Busk, 1876), B. fragilis (Ridley, 1881), $B$. inermis (Busk, 1852), B. magellanica (Busk, 1852), B. maxilla (Jullien, 1888) and B. unicornis (Hastings, 1943) between $35^{\circ}$ and $56^{\circ} \mathrm{S}$, and between $50^{\circ} \mathrm{W}$ and the coast of Argentina has been summarized by López Gappa (2000), and maps showing known records of five species in the Patagonian shelf have been published by López Gappa \& Lichtschein (1990).

These species are usually found in coldtemperate waters under the influence of the Malvinas Current. They have been recorded for the Magellan Strait, Cape Horn, the Burdwood Bank, around the Malvinas (Falkland) Islands, and along the coast and continental shelf off the provinces of Tierra del Fuego, Santa Cruz and Chubut. Only B. maxilla extends further north in Argentina, towards deeper shelf areas off the province of Buenos Aires (Roux et al., 1988).

A little known species, B. australis Busk, 1852, can be added to the list of Argentine species of this genus. It was originally described from material collected by Charles Darwin in Patagonia and Cape Horn, although without giving precise localities within this region. $B$. australis was found again just once, off the state of São Paulo, Brazil. This unlikely distribution was confirmed, however, by the comparison of the Brazilian material with the type specimens of the species (Marcus, 1937).

While processing intertidal and subtidal samples of benthic invertebrates from the Gulf of San Matias, several colonies of a species of Beania still unrecorded for Argentina were discovered. It was identified as Beania mirabilis Johnston, 1840, a widely distributed species, whose southern distribution limit known to date in the southwest Atlantic Ocean was Brazil. The aim of this study is to document its presence in coastal waters of Argentina. In addition, an illustrated key for the Argentine species of Beania is presented, in order to facilitate their identification by other marine researchers not familiar with the taxonomy of this group of benthic invertebrates.

Beania mirabilis Johnston, 1840 (Figs. 1, 2)

Beania mirabilis Johnston, 1840: 272, figs, 1, 2 , Beania mirabilis: Marcus, 1937: 60, pl. XII, fig. 29 (Synonymy).

Beania mirabilis; Ryland \& Hayward, 1977: 150, fig. 73. 


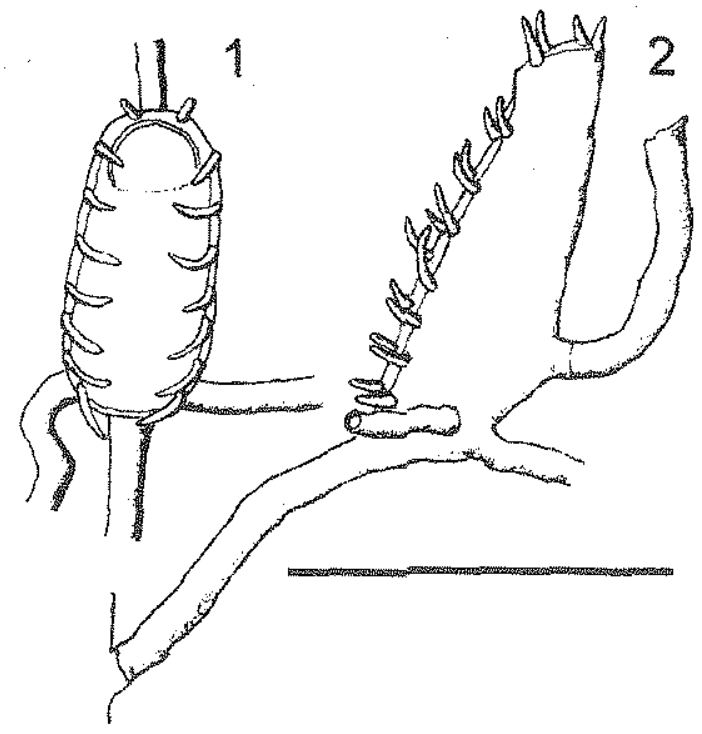

Figs. 1-2. Beania mirabilis Johnston, 1840. Punta Delgado, Gulf of San Matias, MACN 34615. Scale: $0.5 \mathrm{~mm}$. 1, Frontal view of zooid. 2, Lateral view of zooid.

\section{Diagnosis}

Colony uniserial, ramified. Zooids suberect, $0.55-0.60 \mathrm{~mm}$ long, spaced 1.1-1.7 zooid lengths from each other, anchored to the substratum by rhizoids and connected by stolons. Three stolons per zooid, issuing latero- and medio-proximally from the base of the zooid. Two pairs of short and erect spines around the operculum. Usually 6 (sometimes 7 or 8 ) pairs of short and delicate spines on each lateral margin, arched over the frontal membrane. Avicularia and ovicells absent.

\section{Material}

Punta Delgado, Gulf of San Matías, province of Río Negro, Argentina (approximately $40^{\circ} 46^{\prime}$
$\left.\mathrm{S}, 64^{\circ} 55^{\prime} \mathrm{W}\right)$. Low intertidal and subtidal $(0-5$ m), Van Veen grab. 26/03/99, collected by J. López Gappa. MACN 34615. On Brachidontes rodriguezi shells and polychaete tubes.

\section{Geographic Distribution}

$B$. mirabilis is widely distributed in temperate and tropical waters of the Atlantic, Indian and Pacific Oceans, although its geographic range seems to be based on more than one species (see below). In the south Atlantic, it has been previously recorded only for Santa Helena Island (Marcus, 1938) and São Paulo, Brazil $\left(24^{\circ} \mathrm{S}\right)$ (Marcus, 1937). Its southern distribution limit in this ocean is therefore extended in more than $16^{\circ}$ of latitude. From the intertidal zone up to a depth of $130 \mathrm{~m}$ (Marcus, 1937).

\section{Observations}

Inconspicuous colonies of this species were found in the intertidal zone, on shells of the mytilid Brachidontes rodriguezi densely encrusted by spirorbid polychaetes. Less frequent substrata were stones and the mussel Mytilus edulis platensis. Other members of this association were the rodophyte Polysiphonia sp., the bryozoan Cryptosula pallasiana and sponges. In subtidal samples, $B$. mirabilis was found on $B$. rodriguezi shell fragments cemented to polychaete tubes, together with the bryozoan Celleporella hyalina.

In a recent study, Tilbrook et al. (2001) reported that several specimens apparently belonging to $B$. mirabilis from Australia, Vanuatu and the Mediterranean, might actually be regarded as new species. Differences in zooid length and spacing, and number of marginal spines between the Patagonian material and British specimens of $B$. mirabilis are very slight, and do not seem to justify the introduction of a new species.

\section{KEY TO THE ARGENTINE SPECIES OF BEANIA}

1. Usually one or two avicularia per zooid, facing frontally .......................................... 2

- Avicularia absent, or less frequent and pointing towards the basal surface of the colony ..... 4

2. Marginal spines arched over the frontal membrane. Usually one avicularia per zooid ......... 3

- Marginal spines absent, Two avicularia per zooid ............................... B. magellanica (Fig. 3)

3. Three pairs of erect spines around the operculum. Operculum bearing one pair of irregularly star-shaped processes ................................................................................... B. maxilla (Fig. 4)

- Two pairs of erect spines around the operculum. Operculum bearing one pair of horn-shaped

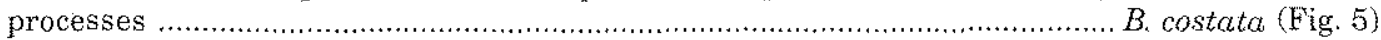

4. Zooids prostrated, more or less horizontal .................................................................. 5

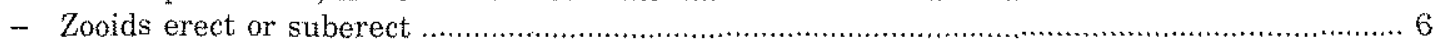

5. Marginal spines delicate, scarce and scattered, Zooids contiguous .............. B. inermis (Fig. 6) 

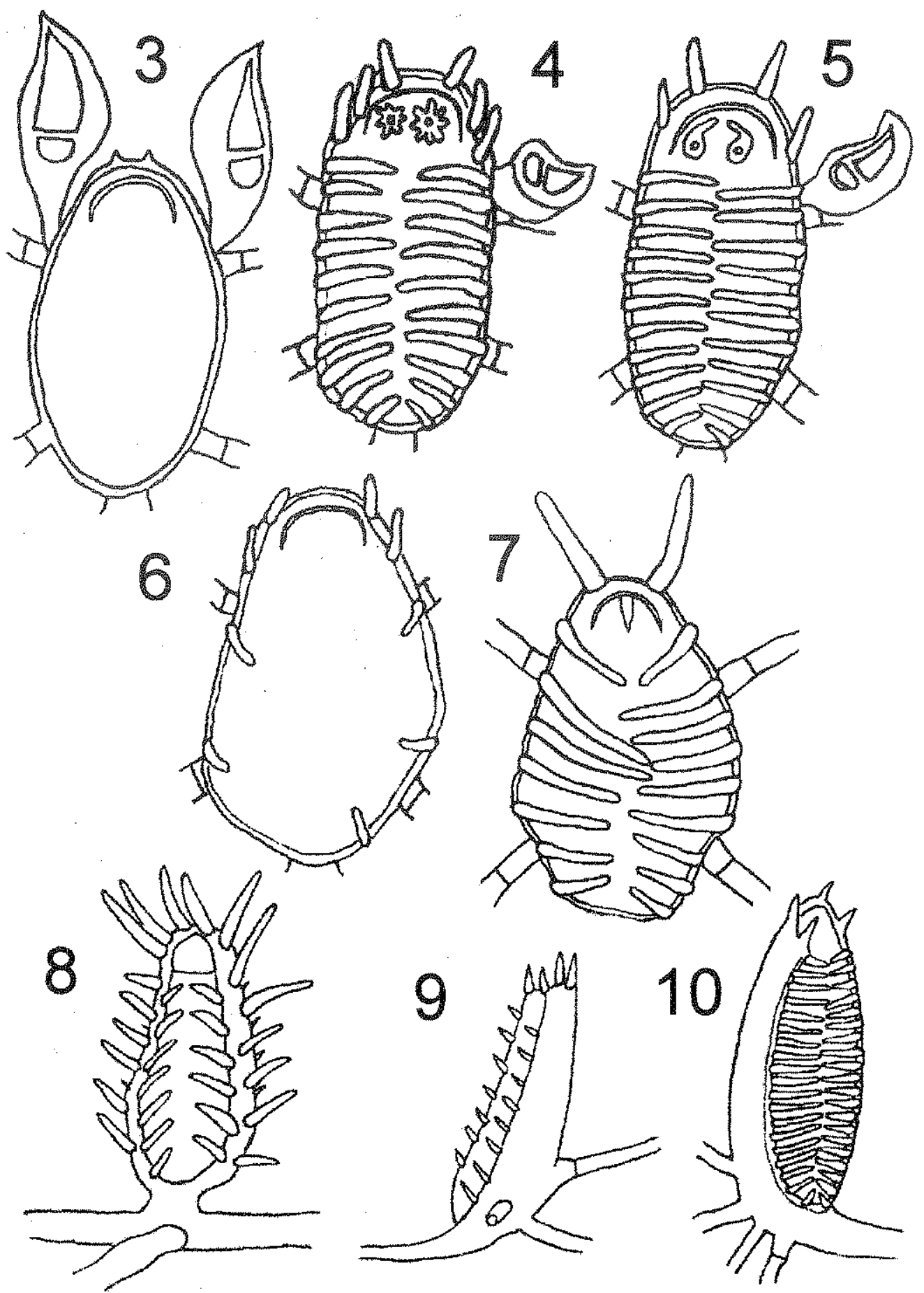

Figs, 3-10. Schematic view of zooids in the 8 species of Beania recorded for Argentina. 3, Beania magellanica. 4, B. maxilla. 5, B. costata. $6, B$ inermis. $7, B$. unicornis. 8 , B. fragilis. $9, B$. mirabilis. 10, B. australis. Figs. 3-7, frontal view, Figs. 8-10, lateral view. Not to scale. Modified from López Gappa \& Lichtschein (1990) (Figs. 3-5 and 8), Amor \& Pallares (1965) (Fig. 6), Hastings (1943) (Fig. 7), Ryland \& Hayward (1977) (Fig. 9), and Marcus (1937) (Fig. 10). 
- Numerous and well developed marginal spines. Zooids well separated among each other B. unicornis (Fig. 7)

6. Spines numerous, long, and conspicuous, located even at the dorsal surface of the zooid, pointing in all directions B. fragilis (Fig. 8)

- Spines only along the edge of the frontal membrane, or around the operculum 7

7. Spines short and delicate, not covering the frontal membrane B. mirabilis (Fig, 9)

- Two series of well developed spines covering the frontal membrane B. australis (Fig. 10)

\section{ACKNOWLEDGEMENTS}

I am indebted to Ana Mercado Laczkó and Alejandro Tablado for their advice on the use of software for the design and edition of digital images. The National Council for Scientific Research and Technology (CONICET) of Argentina is gratefully acknowledged for financial support to the author during the course of this study.

\section{BIBLIOGRAPHY}

Amor, A. \& R. Pallares. 1965. Entoprocta y Ectoprocta de la Ría Deseado (Santa Cruz, Argentina) y otras localidades patagónicas. Physis (Buenos Aires), 25: 291-317.

Busk, G. 1852. Catalogue of the marine Polyzoa in the collection of the British Museum. Part 1 . Cheilostomata (part), pp. 1-54. Trustees of the British Museum (Natural History), London.

- 1876. Description of some new species of Polyzoa from Kerguelen's island. Ann. Mag. Nat. Hist., ser. 4, 17: 116-118.

Hastings, A.B. 1943. Polyzoa (Bryozoa). I. Scrupocellaridae, Epistomidae, Farciminaridae, Bicellariellidae, Aeteidae, Scruparidae. Discovery Rep. 32: 301-510.

Johnston, G. 1840. Description of a new genus of British zoophyte. Ann. Mag. Nat. Hist, ser. 1, 5: 272-274.

Jullien, J. 1888. Bryozoaires. Miss. Sci. Cap Horn (1882.
1883), Zool. 6: 1+94. Gauthier-Villars et Cie, Paris. López Gappa, J. 2000. Species richness of marine Bryozoa in the continental shelf and slope off Argentina (south-west Atlantic). Diversity and Distributions, $6 ; 15-27$.

López Gappa, J. \& V. Lichtschein. 1990. Los briozoos coleccionados por el B/I Shinkai Maru en la plataforma continental argentina. Serv. Hidrogr. Naval, Buenos Aires, 32 pp.

Marcus, E. 1987. Bryozokrios marinhos brasileiros. I. Bol. Fac. Phil. Sci. Letr. Univ. São Paulo I, Zool. 1: 1-224.

- 1938. Papers from Dr. Th. Mortensen's Paciric Expedition 1914 - 16. LXIX. Bryozoen von St. Helena. Vidensh. Medd. Dansk. Naturh. Foren, 101: $183-252$.

Ridley, S.O. 1881. Polyzoa. Account of the zoological collection during the survey of H.M.S. Alert in the Strait of Magellan and on the coast of Patagonia. Proc. Zool. Soc., pp. 44-61.

Roux, A., Bastida, R., Lichtschein, V. \& A. Barreto. 1988. Investigaciones sobre las comunidades bentónicas de plataforma a través de una transecta frente a Mar del Plata.Spheniscus 6: 19-52.

Ryland, J.S. \& P.J. Hayward. 1977. British Anascan bryozoans. Synopses of the British fauna (n.s.), 10. Academic Press, London, 188 pp.

Tilbrook, K.J., Hayward, P.J. \& D.P. Gordon. 2001. Cheilostomatous Bryozoa from Vanuatu. Zool. J. Linn. Soc. 131: 35-109.

Recibido: 31 -VITH-2000 Aceptado: 15-XII-2000 